\title{
歯原性角化囊胞の角化のタイプによる臨床病理学的相違
}

\author{
岩㴊博史・矢郷香・田中陽一* \\ 今谷哲也·本間宏昌・須佐美英作 \\ 柴 秀行·岡田豊·朝波惣一郎
}

\section{Clinicopathological variants of the keratinization type of odontogenic keratocyst}

\author{
Hiroshi IwabuchI $\cdot$ Kaori Yago $\cdot$ Youichi TAnAKA* \\ Tetsuya Imatani $\cdot$ Hiromasa Honma $\cdot$ Eisaku Susami \\ Hideyuki Shiba $\cdot$ Yutaka Okada $\cdot$ Souichiro Asanami
}

\begin{abstract}
We comparatively studied differences in clinicopathological features according to the keratin type of the epithelium of the cyst wall and differences in cell kinetics using antibodies against PCNA in 33 patients with odontogenic keratocysts (36 cysts). The subjects presented at the patient clinic of our department during the 17 years from 1979 to 1995 and satisfied the histopathological criteria described by Pindborg et al. When classified according to the keratin type of the cyst-wall epithelium, there were 7 (19.4\%) cysts with orthokeratin (group I ), $5(13.9 \%)$ cysts with parakeratin accompanied by partial orthokeratin (group II ), and $24(66.7 \%)$ cysts with parakeratin (group III). The average age of group I was slightly younger than that of group III. The number of women was higher than that of men in group I, while men slightly outnumbered women in the group III. No cysts in group I were associated with basal cell nevus syndrome. The form of all cysts was unilocular in the group I, while in group III, cysts showed various forms, including multilocular cysts. The number of cysts with impacted teeth was higher in group III than in the other two groups. The size of some cysts was $8 \mathrm{~cm}$ or larger in group III, while in the group I, there were no cysts of $8 \mathrm{~cm}$ or larger. No significant differences were observed in the PCNA-positive rate between group I and III.
\end{abstract}

Key words: odontogenic keratocyst (歯原性角化囊胞), antibody against PCNA (抗 PCNA 抗体), orthokeratin (正角化), parakeratin (錯角化), basal cell nevus syndrome（基底細胞 母斑症候群)

慶應義塾大学医学部歯科口腔外科学教室

(主任 : 名波智章教授)

*東京歯科大学市川総合病院臨床検査部病理

(主任 : 小出 紀教授)

Department of Dentistry and Oral Surgery, School of Medicine, Keio University (Chief: Prof. Tomoaki Nanami )

${ }^{*}$ Clinical Laboratory, Surgical Pathology, Ichikawa General Hospital Tokyo Dental College (Chief: Prof. Osamu Koide)

受付日：平成 7 年 6 月 20 日
緒 言

歯原性角化囊胞は, 多発性や再発率が高いこと, ま た悪性化することなどが注目されており, 病理組織学 的にも，特徴的な所見を示す．また裏装上皮の角化は， 錯角化が多いが正角化の場合もあり，その再発率は錯 角化に比べ低いとの報告 ${ }^{1)}$ もある。また近年, DNA polymerase $\delta$ の補助因子で, DNA の合成に関連し た蛋白として核内に存在し，細胞周期の $G_{1}$ 期 $S$ 期 に増加する PCNA（増殖細胞核抗原, proliferating 
表 1 臨床的検討 ( 1 )

\begin{tabular}{|c|c|c|c|c|}
\hline \multicolumn{2}{|c|}{ 角化のタイプ* } & I 群 & II 群 & 正群 \\
\hline \multirow{2}{*}{ 症 例 数 } & (例) & 6 & 5 & 22 \\
\hline & （囊胞） & 7 & 5 & 24 \\
\hline \multicolumn{2}{|c|}{ 年 齢（歳） } & 27.8 & 27.4 & 34.0 \\
\hline \multicolumn{2}{|c|}{ 男女比（男：女） } & $1: 2$ & $3: 2$ & $4.3: 3$ \\
\hline \multicolumn{2}{|c|}{ 基底細胞母斑症候群（例） } & 0 & 1 & 3 \\
\hline \multirow{2}{*}{$\begin{array}{c}\text { 震胞の数 } \\
(\text { 例 })\end{array}$} & 単発 & 5 & 5 & 20 \\
\hline & 多発 & 1 & 0 & 2 \\
\hline \multirow{3}{*}{$\begin{array}{c}\text { 囊胞の形状 } \\
\text { (襄胞) }\end{array}$} & 単胞性（類円形） & 7 & 2 & 14 \\
\hline & 単胞性（辺縁不正） & 0 & 2 & 5 \\
\hline & 多胞性 & 0 & 1 & 5 \\
\hline \multicolumn{2}{|c|}{ 埋伏歯有（16 襄胞） } & 1 & 3 & 12 \\
\hline \multirow{3}{*}{ 埋伏歯の部位 } & $\overline{5}$ & 1 & 1 & 0 \\
\hline & $\overline{8}$ & 0 & 1 & 9 \\
\hline & $\underline{8}$ & 0 & 1 & 3 \\
\hline \multirow{2}{*}{$\begin{array}{c}\text { 埋伏歯と } \\
\text { 襄胞関係 }\end{array}$} & 歯牙全体 & 1 & 2 & 4 \\
\hline & 歯冠のみ & 0 & 1 & 8 \\
\hline \multirow{4}{*}{$\begin{array}{c}\text { 震胞内容液 } \\
(\text { 襄胞 })\end{array}$} & 角化物 & 4 & 3 & 11 \\
\hline & 膿性 & 2 & 1 & 5 \\
\hline & 無 & 1 & 1 & 3 \\
\hline & 漿液性 & 0 & 0 & 5 \\
\hline \multirow{3}{*}{$\begin{array}{c}\text { 襄胞の大きさ } \\
\text { (囊胞) }\end{array}$} & $4 \mathrm{~cm}$ 末満 & 6 & 2 & 13 \\
\hline & $4 \mathrm{~cm}$ 以上 $8 \mathrm{~cm}$ 末満 & 1 & 3 & 6 \\
\hline & $8 \mathrm{~cm}$ 以上 & 0 & 0 & 5 \\
\hline \multicolumn{2}{|c|}{ 再発率(\%) } & 0 & 0 & 0 \\
\hline
\end{tabular}

*I 群：褧胞壁上皮が全周正角化タイプを示すもの

II 群 : 襄胞壁上皮が錯角化で一部正角化タイプを示すもの

III 群：軎胞壁上皮が全周錯角化タイプを示すもの

cell nuclear antigen) に対するモノクロナール抗体 (抗 PCNA 抗体) が開発され増殖能を示す細胞を同定 することが可能となった。そこでわれわれは，歯原性 角化囊胞に対し，囊胞壁上皮の角化のタイプ別による 臨床病理所見の相違および抗 PCNA 抗体を用いて細 胞動態の差を比較検討し, 若干の知見を得たので報告 する。

\section{対象および方法}

対象症例は, 1979 年〜1995 年の 17 年間に当科を受 診し, 入院手術を施行し, Pindborg $5^{2)}$ の病理組織 学的診断基準を渵たした歯原性角化囊胞 33 例（36囊 胞）である。これらの襄胞は，すべて全摘出されてお
り，また標本作成法は，一部古いものでは不明である が, その他のものは，摘出物をすべて包埋した.

病理検査法は, 包埋した標本を $\mathrm{HE}$ 染色し，囊胞壁 上皮の角化の夕イプを全周正角化タイプ, 錯角化で一 部正角化タイプ, 全周錯角化タイプに分けた.

臨床的検討は, 年齢, 男女比, 基底細胞母斑症候群 の有無, 囊胞の数 (単発, 多発), 囊胞の形状 (単胞性 類円形, 単胞性辺縁不正形, 多胞性), 埋伏歯の有無, 埋伏歯の部位, 埋伏歯と囊胞の関係（歯牙全体を含む， 歯冠のみを含む), 囊胞内容液 (角化物, 膿性, 無, 漿 液性), 囊胞の大きさ $(4 \mathrm{~cm}$ 未満, $4 \mathrm{~cm}$ 以上 $8 \mathrm{~cm}$ 末 満, $8 \mathrm{~cm}$ 以上), 再発率について行った。

抗 PCNA 抗体を用いた比較検討は, 囊胞壁上皮の 角化のタイプが, 正角化と錯角化のものそれぞれ 6 囊 
表 2 臨床的検討 ( 2 )

\begin{tabular}{c|c|c|c}
\hline & I 群 & II 群 & II 群 \\
\hline 下顎智歯部 下顎枝部 & 2 & 2 & 12 \\
\hline 下顎大臼歯部 & 3 & 1 & 5 \\
\hline 上顎智歯部 & 0 & 1 & 3 \\
\hline 下顎小臼歯部 & 1 & 1 & 1 \\
\hline 上顎前菌部 & 0 & 0 & 2 \\
\hline 上顎大臼歯部 & 1 & 0 & 0 \\
\hline 下顎前歯部 & 0 & 0 & 1 \\
\hline
\end{tabular}

胞, 計 12 震胞で行った. 抗 PCNA 抗体を用いた免疫 組織染色は, $\mathrm{DAKO}$ 社製の $\mathrm{ABC}$ キットを用いて行っ た. 脱パラフィン後, microwave ovenによる賦活化 を行い, その後は通法 ${ }^{3)}$ 通りに行った. PCNA 陽性 率は 400 倍で検鏡し, 炎症程度の低い部位を選び, 視 野中に見られた豊胞壁上皮の基底細胞数を数えた．部 位を変え細胞数が 1000 個になるまで数え，1000 細胞 中にみられた PCNA 陽性細胞数を百分率で表した. 陽性細胞の判定は, 核が褐色の染色性を明らかに示し たものを陽性細胞とした。 また,この算定は囊胞壁上 皮の基底層と, 基底層の上 2 層の傍基底層の 2 層に分 けて行った。なお検定は wilcoxon 検定にて行った。

\section{結果}

\section{1. 襄胞壁の角化のタイプ}

囊胞壁上皮の角化のタイプは，正角化 7 襄胞 (19.4\%) ( I 群), 錯角化で一部正角化 5 囊胞 (13.9\%) （II 群），錯角化 24 囊胞 (66.7\%)（四群）であった.

\section{2 . 臨床的検討 (表 1,2 )}

平均年齢は I 群 27.8 歳, II 群 27.4 歳, III 群 34.0 歳 であった，男女比は，I群では男性：女性は $1 ： 2$ で

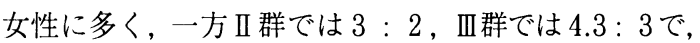
共に若干男性に多く認められた。基底細胞母玟症候群 は III 群 3 例で II 群に 1 例，I群には認められなかった。

$\mathrm{X}$ 線所見から発生部位は，I 群，II 群，III群共に下 顎大臼歯部から下顎智歯部に多く認められ，I 群では 5 囊胞 $(71.4 \%)$, II 群では 3 震胞 $(60.0 \%)$, III 群では 17 襄胞 $(70.8 \%)$ であった.

$\mathrm{X}$ 線および手術所見から囊胞の数は, I 群, II 群, III群共に単発が多く，I 群では 5 例 $(83.3 \%)$, II 群で は 5 例 $(100.0 \%)$ ， II 群では 20 例 $(90.9 \%)$ であった。 囊胞の形状は I 群では 7 鞛胞すべてが単胞性類円形で あった，四群では, 単胞性類円形が 14 囊胞と多いが, 多胞性も5 囊胞認められた。埋伏歯の有無は, 埋伏歯
表 3 PCNA 陽性率

\begin{tabular}{|c|c|c|c|c|c|}
\hline $\begin{array}{l}\text { 角化の } \\
\text { タイプ }\end{array}$ & $\begin{array}{l}\text { 症例 } \\
\text { 番号 }\end{array}$ & $\begin{array}{l}\text { 埋伏歯 } \\
\text { の有無 }\end{array}$ & $\begin{array}{c}\text { 基底層 } \\
(\%)\end{array}$ & \begin{tabular}{|c} 
傍基底層 \\
$(\%)$
\end{tabular} & 平均 \\
\hline \multirow{7}{*}{ I 群 } & 1 & 無 & 1.5 & 4.2 & \multirow{6}{*}{3.55} \\
\hline & 2 & 無 & 5.0 & 7.5 & \\
\hline & 3 & 無 & 1.0 & 0.0 & \\
\hline & 4 & 無 & 1.9 & 1.4 & \\
\hline & 5 & 無 & 7.4 & 5.8 & \\
\hline & 6 & 有 & 3.7 & 3.2 & \\
\hline & \multicolumn{2}{|c|}{ 平 均 } & 3.41 & 3.68 & \\
\hline \multirow{7}{*}{ III 群 } & 7 & 無 & 1.1 & 2.4 & \multirow{6}{*}{2.81} \\
\hline & 8 & 無 & 5.9 & 9.1 & \\
\hline & 9 & 無 & 1.5 & 3.3 & \\
\hline & 10 & 無 & 1.0 & 1.9 & \\
\hline & 11 & 無 & 1.9 & 5.3 & \\
\hline & 12 & 有 & 0.2 & 0.1 & \\
\hline & \multicolumn{2}{|c|}{ 平 均 } & 1.93 & 3.68 & \\
\hline \multicolumn{3}{|c|}{ 全 平 均 } & 2.68 & 3.68 & \\
\hline
\end{tabular}

を含んでいたのは I 群では， 1 襄胞 $(16.7 \%)$ で発生 部位は下顎小臼歯であった． III群では 12 囊胞 (50.0\%) で, 下顎智歯が 9 囊胞と多かった。埋伏歯と囊胞の関 係はI 群では，歯牙全体が囊胞中に含まれていた，III 群では, 4 震胞が歯牙全体, 8 囊胞が歯冠のみ襄胞中 に含まれていた，囊胞内容液は I 群では，漿液性であっ た症例はなく, 角化物か膿性であった。四群では, 角 化物 11 震胞, 膿性 5 襄胞, 漿液性 5 襄胞で, 角化物が 約半数であった．囊胞の大きさは，I 群では $4 \mathrm{~cm}$ 未 満 6 囊胞, $4 \mathrm{~cm}$ 以上 $8 \mathrm{~cm}$ 未満 1 震胞で, II 群では

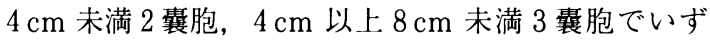
れも $8 \mathrm{~cm}$ 未満の囊胞であった。四群では, $8 \mathrm{~cm}$ 以上 の巨大な震胞が 5 襄胞存在した.

\section{PCNA 陽性率（表 3 ）}

I 群, III群 6 襄胞ずつ計 12 襄胞について検討した 結果, PCNA 陽性細胞が, 基底層に多く認められる夕 イプと, 傍基底層に多く認められる夕イプが観察され た。 I 群と III 群を合わせた基底層と傍基底層の PCNA 陽性率は，基底層では $0.2 \% \sim 7.4 \%$ (平均 $2.68 \%$ ) で，傍基底層では $0 \% \sim 9.1 \%$ (平均 3.68\%) であったＩ群と四群それぞれの基底層と傍基底層の PCNA 陽性率を観察してみると，I 群の基底層では $1.0 \% \sim 7.4 \%$ （平均 3.41\%）で，傍基底層では 0 \% 7.5\%（平均 3.68\%）であった。 II 群の基底層で は $0.2 \% \sim 5.9 \%$ (平均 $1.93 \%$ ) で, 傍基底層では 0.1 \% $9.1 \%$ (平均 3.68\%) であった. 基底層と傍基底層 それぞれの，I群と四群の PCNA 陽性率を観察して 

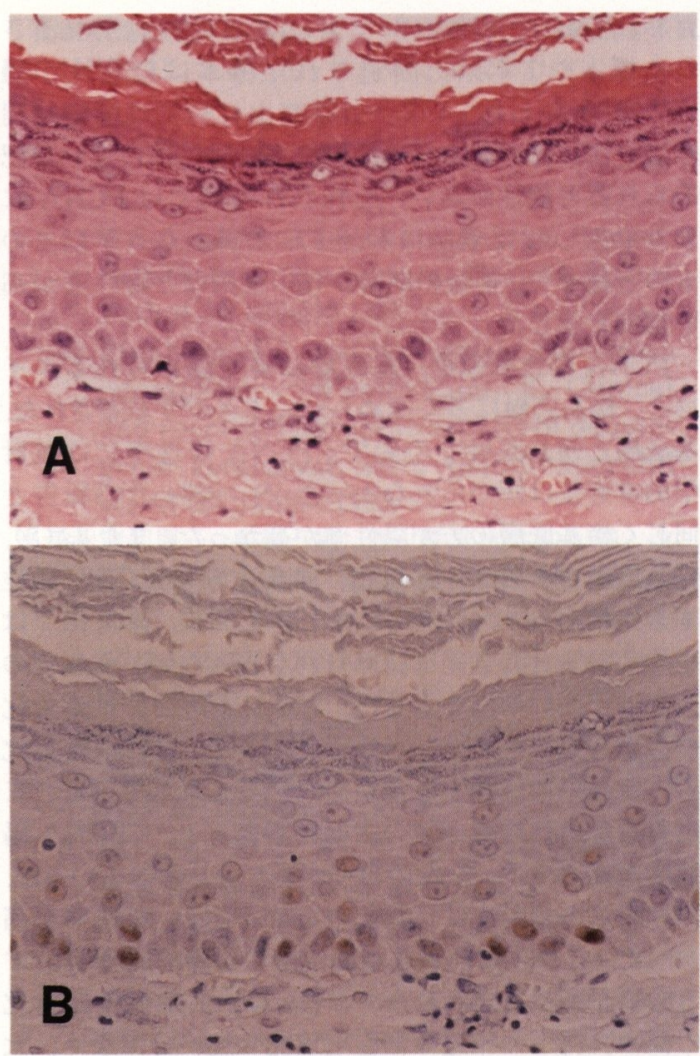

写真 1 I 群の病理組織像 (症例 6 )

A : H.E 染色 $\times 400$

裏装上皮は角化重層扁平上皮で角化層は正角化を示 している.

B : PCNA 染色 $\times 400$

基底層, 傍基底層に PCNA 陽性細胞が認められる.
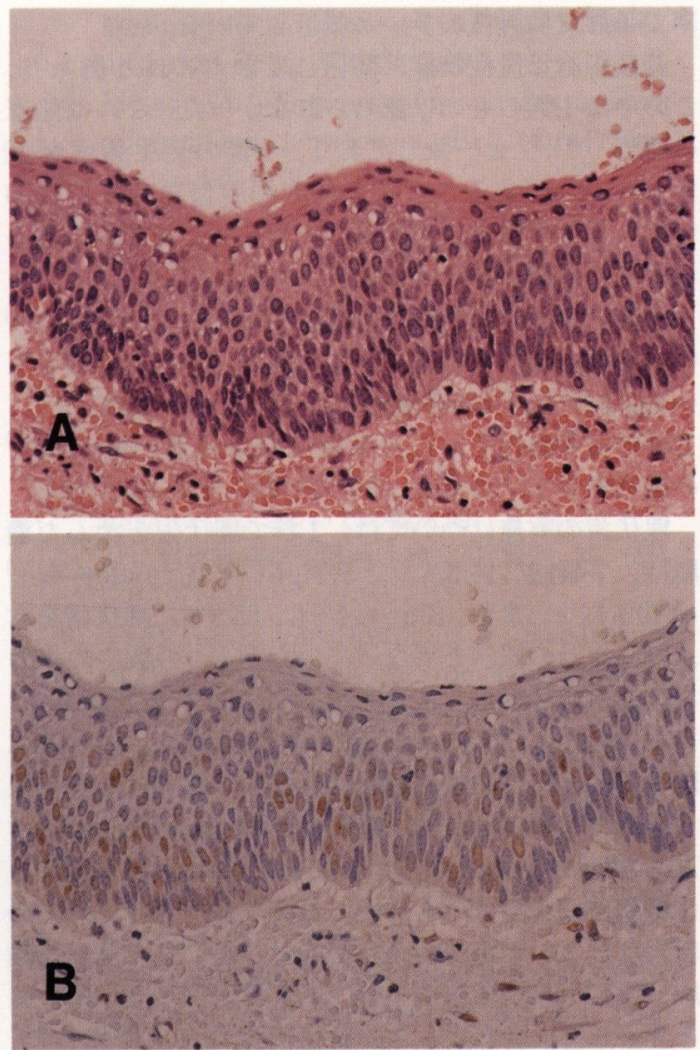

写真 2 III 群の病理組織像 (症例 11)

A : H.E 染色 $\times 400$

裏装上皮は角化重層扁平上皮で角化層は錯角化を示 している.

B : PCNA 染色 $\times 400$

基底層, 傍基底層に核が褐色に染色された細胞が認 められる。このうち明らかに褐色に染色された核を 有する細胞を陽性とした。

II 群が 5 囊胞 (13.9\%), III群が 24 囊胞 (66.7\%), であつ た. 正角化タイプの発生頻度には種々の報告があるが,

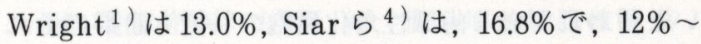
$18 \%$ との報告 $1 ４$ 4 6 ) が多く自験例とほほ一致してい た.

\section{2. 臨床的検討について}

平均年齢は I 群 27.8 歳, III 群 34.0 歳で III 群の方が 若干年齢が高かった.これは Crowley ら ${ }^{8)}$ の報告と 一致していた。また I 群の平均年齢は本邦の報告 7) では 25 歳で, 自験例とほほ同じであった。欧米では 32 歳から 35 歳の報告 $1,4,7)$ が多く, 自験例より若干 高かった. 男女比は，I群では女性に多く，皿群では 男性に多く認められた。しかし Wright ${ }^{1}$ ), Siar ら ${ }^{4}$ ， Vuhahula ( $^{8)}$ はI 群は男性に多く認められたと報 告している。またCrowley ら ${ }^{7)}$ は I 群は男女ほほ同
1. 裏装上皮の角化のタイプについて

囊胞壁上皮の角化のタイプは I 群が7 囊胞 (19.4\%), 
率で而群では男性に多いと報告している。

基底細胞母斑症候群に関係していたのは 4 例あり， この中にI群のものは認められなかった。これは諸家 の報告 $1,4,8)$ と一致しており，I群の発生頻度が 12 \%から 18\%であることから基底細胞母斑症候群にお いてもI群の歯原性角化囊胞を発見することができる はずであるが, その様な報告はなかった。

I 群のものでは多発は非常にまれであり, Wright ${ }^{1}$ ) は多発性の正角化型歯原性角化囊胞はないと報告して いる.しかし，今回の検討では 1 例認められた。また， I 群では多胞性を示した症例はなかった. Wright ${ }^{1}$ ) の報告でも $1 / 60$ 囊胞 $(1.7 \%)$ のみであった.

埋伏歯の有無については, I 群で埋伏歯を含んだ囊 胞は，1囊胞 (14.3\%) で Wright ${ }^{1}$ ), Crowley ら 7) は70\%以上, また, Siar ら 4) も, $55.6 \%$ に埋伏歯を含 んでいたとの報告と異なっていたが,この数字の大き な相違は今後症例を増やし検討していく必要がある. また, 埋伏茵の部位, 埋伏苗と囊胞の関係, 内容液に 関してはI 群，III群で相違は認められなかった。

囊胞の大きさはI 群では $4 \mathrm{~cm}$ 未満が $85.6 \%$ あ， 逆に四群では $4 \mathrm{~cm}$ 末満が $54.2 \%$ で, $8 \mathrm{~cm}$ 以上の大き な囊胞が $20.8 \%$ 認められた。囊胞の大きさについての 報告は少ないが歯原性角化囊胞は一般に他の歯原性囊

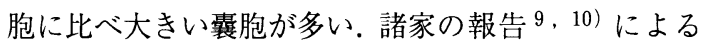
と $3 \sim 5$ 歯程度の大きさの囊胞が半数以上であった. しかし, Wright $\left.{ }^{1}\right)$ は I 群の $72 \%$ が 1 - $3 \mathrm{~cm}$ の大き さであったと報告しており, 自験例でも I 群は四群に 比べ囊胞の大きさが小さくまた $8 \mathrm{~cm}$ 以上の大きい囊 胞はすべて III群であった。このことより, 多胞性で巨 大な囊胞を形成すると言われている歯原性角化囊胞の 特徴は品群のそれを言ったものであり，I群の歯原性 角化囊胞では異なる性状を有する事が示唆された。

本研究では観察期間が短いこともあり, 再発した症 例は認められなかったが, 歯原性角化囊胞の再発率は $12.0 \%$ 62.5\% と報告 $2,11 \sim 21)$ されており, 平均 $20 \%$ である。しかしＩ群の再発率は０\% 2.2\%と報 告 $1,7,8,13)$ されている.このことより, 再発率が高 いと言われている歯原性角化囊胞の特徴も III群のそれ を言ったものであり, I 群の歯原性角化囊胞では異な る性状を有する事が示唆された。

上記より I 群は, 発生機序の上から III群とは別個の ものであるの可能性が示唆された. 矢郷ら 22) は過去 の報告によるとI 群の歯原性角化囊胞を顎骨内の類表 皮裳胞としている可能性が高く, また I 群の歯原性角 化囊胞を顎骨内の類表皮囊胞とすることには疑問があ ると報告しており, 著者らも同様の考えであり, 顎骨 内の類表皮囊胞の明確なクライテリマが必要であると 思われた。

\section{PCNA 陽性率について}

PCNAの染色性は固定条件に影響されやすい23）と
言われており，10\%ホルマリンに48時間以上浸漬さ れた標本や 1 年以上固走された標本は染色性が悪 い24,25) といわれている. 外科摘出材料では固定時間 や固垐法に差があるため怔例により陽性率に違いが認 められる可能性が䯩い。われわれの例ではPCNAに より染色した 12 襄胞は術後 1 年末満から 5 年以上の ものと種々で, 術後の期間が短い怔例ほど陽性率が高 い傾们を小した。

PCNA 陽性細胞が，基底層に多く認められる夕イ プと, 傍基底層に多く認められたタイプが観察された. 基底層と傍基底層での間で, PCNA 陽性率には統計 学的有意差は認められなかったが, 冲津ら ${ }^{26)}$ の報告と 同じく傍基底層の方が陽性率が高かった。また基底層， 傍基底層をあわせ, 正角化, 錯角化別にPCNA 陽性 率を比較すると, 正角化では平均 $3.55 \%$, 錯角化では 平均 $2.81 \%$ と有意差は認められなかったが, 正角化の 方が若干高い傾们をホした。しかし正角化より錯角化 の方が再発率が高いという報告が多く，これは錯角化 の方が高い増殖能を示すためだと考えられている。ま た歯原性角化囊胞が他の歯原性囊胞に比べ PCNA 陽 性率が高い12，27，28）ため再発が多いといわれているが， われわれの検討では正角化の方が PCNA 陽性率が高 かった。これらは前述した固定等の影響も充分考虑す る必要があると思われた. 著者らは, 正角化と錯角化 の間の再発率の相違は細胞増殖能の違いではなく, 大 きさ, 形態の相違による術中の取り残しが最大の原因 ではないかと考えている。しかしながら新谷ら ${ }^{28)}$ の 報告や, 冲津ら ${ }^{26)}$ の実験結果では正角化に比べ錯角 化の方が PCNA 陽性率が高かったと報告しており， この焦については, 今後の検討が必要であると思われ た。

\section{結語}

1. I 群 (全周正角化) は $19.4 \%$ の発生頻度であつ た。

2. I 群と III群 (全周錯角化) の臨床所見は以下の 点で相違が認められた。

(1)平均年齢は I 群の方が四群に比べ若干若かった。

(2)男女比は I 群は女性に多く III群では若干男性に多 かった。

(3)基底細胞母斑婝候群に起因する怔例は I 群では認 められなかった。

(4)囊胞の形状は I 群はすべて単胞性類円形で四群で は多胞性を認めた。

(5)埋伏歯を伴う怔例は四群に多かった.

(6)囊胞の大きさは血群は $8 \mathrm{~cm}$ 以上の囊胞を認めた が I 群では $8 \mathrm{~cm}$ 以上の怔例はなかった.

3. PCNA 陽性率はI群とIII群との間に統計学的 有意差は認められなかった。 
なお本論の要旨は第 39 回日本口腔外科学会総会 (平成 6 年 11 月 8 日, 名古屋市)において発表した。

\section{参 考 文 献}

1) Wright, J.M.: The odontogenic keratocyst: Orthokeratinized variant. Oral Med Oral Pathol 56: 609-618 1981.

2) Pindborg, J.J. and Hansen, J.: Studies on odontogenic cyst epithelium. II . Clinical and roentogenographic aspects of odontogenic keratocyst. Acta pathol microbil scand 58: 283-294 1963.

3）渡辺慶一, 中根一穂, 他: 酵素抗体法一巻. 改 訂三版, 学際企画, 東京, 1992, 188-190 頁.

4) Siar, C.H. and Ng, K.H.: Orthkeratinized odontogenic keratocyst in Malaysian. Oral Maxillo-fac Surg 26: 215-220 1988.

5) 永峰浩一郎, 江場光芳, 他: 当講座における過 去 11 年間の歯原性角化襄胞症例の検討.日口 外誌 37: 1853-1861 1991.

6）畑毅, 細田 超, 他：歯原性角化襄胞の臨 床病理組織学的検討 日口外誌 34: 470-484 1988.

7) Crowley, T.E., Kaugars, G.E., et al.: Odontogenic Keratocyst. A clinical and histologic comparison of the para keratin and orthokeratin variants. J Oral Maxillofac Surg 50: 22-26 1992.

8) Vuhahula, E., Nikai, N., et al.: Jaw cyst with orthokeratinization. analysis of 12 cases. J Oral Patho Med 22: 35-40 1993.

9) 榎本昭二, 岩佐俊明, 他: 原始性襄胞 (Primordial cyst）の臨床的研究. 日口外誌 23: 121-128 1977.

10）飯野光喜, 松田耕策, 他：歯原性角化曹胞の臨 床ならびに病理組織学的検討 日口外誌 35 : 964-973 1989 .

11) Browne, R.M.: The odontogenic keratocyst. Clinical aspects. Brit. dental J. 128: 225-231 1970.

12) Browne, R.M.: The odontogenic keratocyst. Histological features and their correlation with clinical behaviour. Brit Dent J 131: 249-259 1971.

13) Brannon, R.B.: The odontogenic keratocyst. A clincopathologic study of 312 ases. Part I . Clinical features. Oral Surg 42: 54721976.

14) Rud, J. and Pindborg, J.J.: Odontogenic keratocyst. A follow-up study of 21 cases. J Oral Surg 27: 323-330 1969.

15) Mcivor, J.: The radiological features of odontogenic keratocyst. Br J Oral Surg 10: 116-125 1972 .

16) Donoff, R.B., Guralnick, W.C., et al.: Keratocysts of the jaws. J Oral Surg 30: 800-804 1972 .

17) Forssell, K., Sorvari, T.E., et al.: An analysis of the recurrence of odontogenic keratocyst. Proc Finn Dent Soc 70: 1211341974.

18）内海潔, 福永健一, 他: Odontogenic keratocyst についての臨床的, X 線的，なら びに病理組織学的研究 (抄). 日科誌 26: 6096101977.

19) Vedtofte, P. and Pretorius, f.: Recurrence of the odontogenic keratocyst in relation to clinical and histological features. Int $\mathrm{J}$ Oral Surg 8: 412-420 1979.

20) Donatsky, O. and Hj申rting-hansen, E.: Recurrence of the odontogenic keratocyst in 13 patients with the nevoid basal cell carcinoma syndrome. Int J Oral Surg 9 : 1731791980 .

21）横林敏雄,横林康男, 他 : 歯原性角化囊胞の再 発に関する検討. 日口外誌 30: 1338-1347 1984 .

22）矢郷 香, 田中陽一, 他：角化裏装上皮を有す る顎骨内囊胞の臨床および病理組織学的検討一 第 1 報 : 類表皮囊胞と歯原性角化襄胞一。日口 外誌 40: 841-851 1994.

23) Hall, P.A. and Woods, A.L.: Immunohistochemical markers of cellular proliferation: achievements, problems and prospects. Cell Tissue Kinet 23: 501-522 1991.

24）松野吉宏, 向井 清: 増殖細胞核抗原 (PCNA). 病理と臨床 $9: 879-8831991$.

25）田中一成：抗 PCNA 抗体による増殖細胞核の 染色ーパラフィン切片への応用一。病理と臨床 9 : 791-798 1991 .

26）冲津光久, 大野 純, 他：増殖細胞核抗原 (PCNA) による歯原性角化囊胞の増殖能に関 する検討. 日口診誌 6:280-284 1993 .

27) Toller, P.A.: Autoradiography of explants from odontogenic cyst. Brit D J 131: 57-61 1967.

28）新谷 悟, 多和伸介, 他: 歯原性蓑胞の抗 PCNA 抗体による細胞動態の解析. 日科誌 42: 215-222 1993. 